\title{
Reproductive and recruitment seasons for Penaeus aztecus in the Tamaulipas-Veracruz area, Gulf of Mexico
}

\author{
Pedro Cervantes-Hernández ${ }^{1}$ \& Adolfo Gracia ${ }^{2}$ \\ ${ }^{1}$ Instituto de Recursos, Universidad del Mar, Puerto Ángel, Oaxaca, México \\ ${ }^{2}$ Laboratorio de Ecología Pesquera de Crustáceos, Instituto de Ciencias del Mar y Limnología \\ Universidad Nacional Autónoma de México, Ciudad de México, México \\ Corresponding author: Pedro Cervantes-Hernández (pch@angel.umar.mx)
}

\begin{abstract}
An integral fishery analysis was made for the population of Penaeus aztecus in the TamaulipasVeracruz area from 1974 to 1995. Fourteen age classes between 3 and 16 months old were found, and their respective total abundances were virtually reconstructed (this included shrimp that was caught and shrimp that were not caught in the study area). Age classes were statistically separated into two statistical population indices: the abundance of spawners (or SI index) and the abundance of recruits (or RI index). Time series were generated for these indices to establish when reproductive and recruitment seasons began, ended, and reached maximum abundance. SI index was structured with reproductive ages from 6 to 13 months old, and RI index with young recruits of 4 months old. Reproductive season (or lagoon recruitment) spanned from middle December to early May, with the highest spawners abundance in February. Recruitment season (or marine recruitment) spanned from early April to middle September, with the highest abundance of young recruits during June/July. The seasonal changes in the abundance of spawners were described with lagoon recruitment (in the marine environment). The seasonal changes in the abundance of recruits were described with marine recruitment (between lagoons systems and the marine environment). A higher exploitation level of spawners than for young recruits was recorded. Recently closure seasons are implemented between May and August/September/October. These completely protect marine recruitment, and the lagoon recruitment remains unprotected.
\end{abstract}

Keywords: Penaeus aztecus; brown shrimp; reproduction; recruitment; shrimp abundance; Gulf of Mexico

\section{INTRODUCTION}

The shrimp is an important economic resource in Mexico, and throughout the Gulf of Mexico the main shrimp fishery areas are in: 1) Tamaulipas-Veracruz (TV) where the Madre and Tamiahua Lagoons are located (Fig. 1), 2) Sonda de Campeche and 3) Contoy, Quintana Roo. In the first of these areas, the brown shrimp Penaeus aztecus Ives, 1891 is the most abundant species. In the second area, the white Penaeus setiferus Linnaeus, 1767 and the pink shrimp Penaeus duorarum Burkenroad, 1939 are the most abundant species. In the third area, the red shrimp Penaeus brasiliensis Latreille, 1817 is the most abundant species (Gracia, 2004).

In the Gulf of Mexico, the shrimp fishery operations began in 1950 without neither catch regulation nor a closure season system (Cervantes-Hernández \& Gracia,
2011). Due to the growing over-exploitation, in 1993, an official closure season was implemented throughout the Gulf of Mexico, and within its lagoon systems (currently, this is often implemented from May to August with modifications until September/October) (SAGARPA-INP, 2012). In T-V area maximum, $P$. aztecus catch was recorded at 10,000 t (ArreguínSánchez \& Chávez, 1985), and recently it was recorded at 13,210 t (SAGARPA-CONAPESCA, 2017).

The Mexican Fishery Department has records of commercial shrimp catch classified by size categories from 1972 and 1995, but this information was scarcely used to monitor the P. aztecus fishery based on studies of mortality (Klima, 1989; Arreguín-Sánchez et al., 1997; Gracia, 1997), length growth parameters estimation, and analysis of closure seasons (Gracia, 1997). After 1995, shrimp commercial catch classified by size

Corresponding editor: Luis Miguel Pardo 


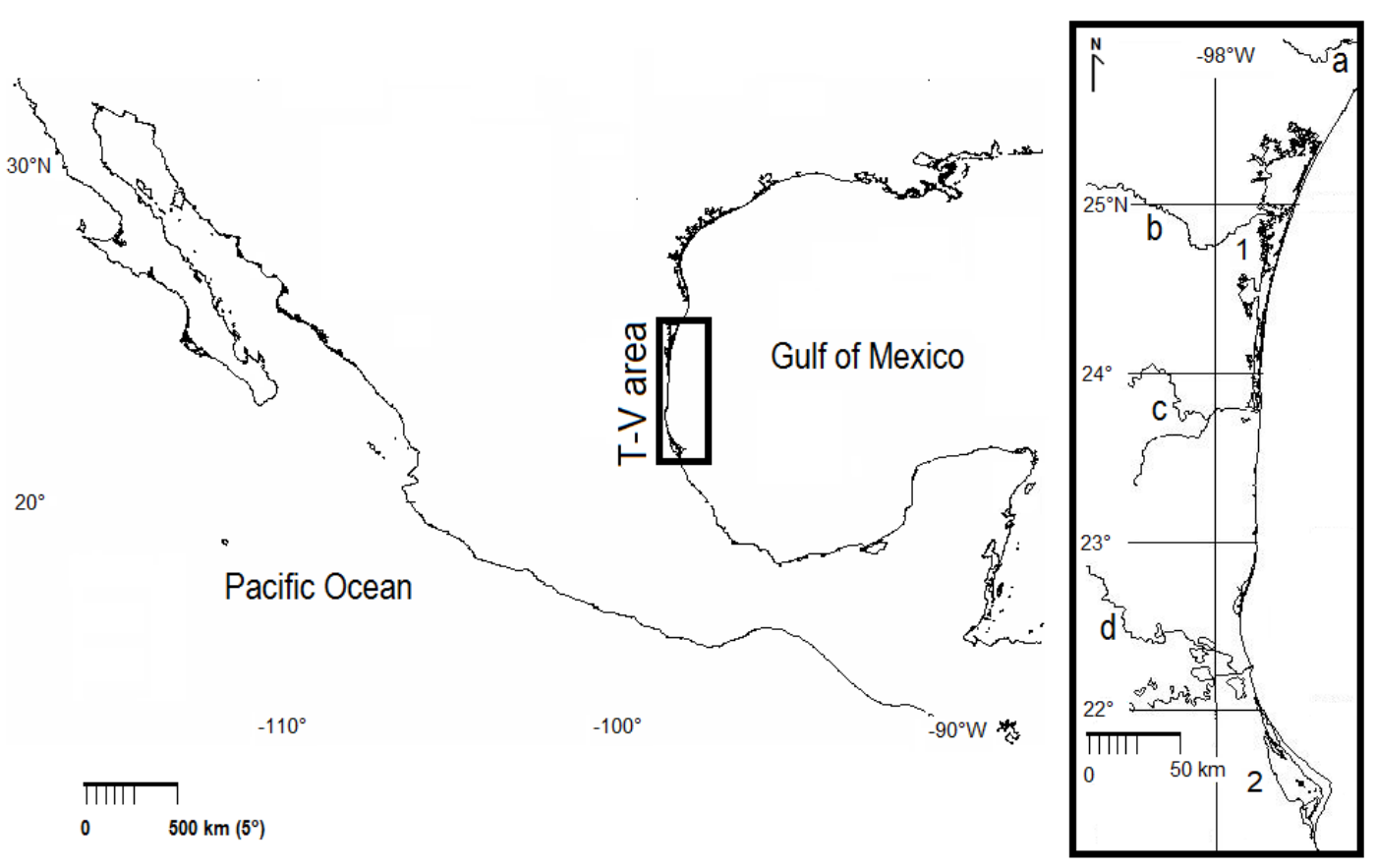

Figure 1. Geographical location of the Tamaulipas-Veracruz area (T-V) in the Gulf of Mexico. The main rivers are: a) Bravo River, b) San Fernando River, c) Soto La Marina River, d) Tamesí River. 1) Mother Lagoon, 2) Tamiahua Lagoon.

categories ceased to be documented in the Gulf of Mexico (Cervantes-Hernández, 2015).

Records of commercial shrimp catch classified by size category are available for the population of Penaeus californiensis Holmes, 1900 in the Gulf of Tehuantepec, Mexico, from 1989 to 1998. These records were used by Cervantes-Hernández (2008) to delimit reproductive and recruitment seasons and this analysis was, in turn, used to perform the first exploitation assessment in this fishery. The author indicated that records of commercial shrimp catch classified by size categories were an excellent tool to monitor shrimp fisheries in this gulf. After 1998, shrimp commercial catch classified by size categories ceased to be documented in the Gulf of Tehuantepec.

As was established, for $P$. aztecus fishery records of commercial shrimp catch classified by size categories have not been thoroughly analyzed to complement studies such as those conducted by CervantesHernández (2008). Therefore, this study aimed to delimit the reproductive and recruitment seasons of $P$. aztecus and perform the first exploitation assessment of this fishery. This analysis can serve to inform on current catch behavior and management of the $P$. aztecus fishery in $\mathrm{T}-\mathrm{V}$ area.

Information about the fishery recruitment of $P$. aztecus was used as a primary resource to perform this study. This recruitment type included all shrimp caught by the fishing effort from 1974 to 1995 , and that was recorded as commercial shrimp catch classified by size categories (10-14, 15-20, 21-25, 26-30, 31-35, 36-40, 41-50, 51-60 and 60 tails per pound).These records were ordered in age classes (Gracia, 1991), and their abundances were approximated with a virtual reconstruct method (Pope, 1972; Hilborn \& Walters, 1992) (these abundance estimates include shrimp that were not caught in T-V area). Afterward, the age classes were statistically separated into two population indices: the abundance of spawners (or SI index) and the abundance of recruits (or RI index). This separation was taken into account to examine the following recruitment types for the population of $P$. aztecus. 1) Lagoon recruitment constitutes the movement of shrimp's post-larvae from the marine environment in T$\mathrm{V}$ area towards inside of the Madre and Tamiahua Lagoons. During this recruitment type, the abundance of spawners increases (Cervantes-Hernández et al., 2017). A time-series analysis was performed with SI index to explain seasonal lagoon recruitment changes (or reproductive seasons) (Cervantes-Hernández, 2008). 2) Marine recruitment constitutes the movement of young shrimp from the aforementioned lagoon system towards the marine environment in $\mathrm{T}-\mathrm{V}$ area. During this recruitment type, the abundance of young shrimp recruits increases (Cervantes-Hernández et al., 2017). A time series was performed with the RI index to explain seasonal marine recruitment changes (or 
recruitment seasons) (Cervantes-Hernández, 2008). Based on the obtained results were established when both recruitment seasons began, ended, and reached maximum abundance in $\mathrm{T}-\mathrm{V}$ area.

Complementary analysis of natural mortality, fishing mortality by age classes, and the first exploitation assessment were provided for $P$. aztecus fishery.

\section{MATERIALS AND METHODS}

Shrimp commercial catch classified by size categories of Penaeus aztecus from 1974 to 1995 was used. This information was recorded by the Mexican Fishery Department (Regional Centers for Fisheries Research from Tamaulipas and Veracruz, Mexico). On the other hand, complete fishery analysis process was made in the Crustacean Fisheries Ecology Laboratory, ICMYL, UNAM, Mexico.

\section{Age classes}

In a study conducted in T-V area, Gracia (1997) examined the commercial landings to generate a total length ( $\mathrm{Lt}$ in $\mathrm{mm}$ ) data set for P. aztecus between 1983 and 1992. The author used this Lt data to construct a size-frequency histogram (Zar, 1999), classifying Lt values into 16 length-ranges. In the present study and for each reported length-range, the mean value for age was calculated (Et in months). These age averages were referred to as the age classes. Thus,

$$
\mathrm{Et}=\left(\mathrm{E}_{\mathrm{es}} / \mathrm{n}\right)
$$

where $E_{e s}$ is the specific age corresponding to each Lt record included at each length-range, and $E_{\mathrm{es}}$ was estimated using Equation 3 indicated below (GómezMárquez, 1994), where $\mathrm{n}$ is the total number of $\mathrm{Lt}$ records at each length-range.

Gracia (1997) compiled and reported the length growth parameters for P. aztecus (Eq. 2), but this author did not mention the respective literature consulted [the asymptotic length $\mathrm{L}_{\infty}=204 \mathrm{~mm}$, hypothetical age at zero $t_{0}=0.2914 \mathrm{~mm}$, and the metabolic monthly growth rate of the shrimp body $\mathrm{k}=0.215]$.

$$
\mathrm{Lt}=\mathrm{L}_{\infty} \times\left[1-\exp \left(-\mathrm{k} \times\left(\mathrm{E}_{\text {es }}-\mathrm{t}_{0}\right)\right.\right.
$$

The Lt data and length growth parameters are known in Equation 2, except for the $\mathrm{E}_{\mathrm{es}}$ parameter, which was calculated from Equation 3. Thus,

$$
\mathrm{E}_{\mathrm{es}}=\left[(1 / \mathrm{k}) \times \ln \left(\mathrm{L}_{\infty} /\left(\mathrm{L}_{\infty}-\mathrm{Lt}\right)\right]+\mathrm{t}_{0}\right.
$$

Estimated age classes were arranged in ascending order from the youngest to the oldest, and with this information, a matrix called $\mathrm{N}$ matrix was partially constructed, consisting of $i$ rows (the months) and $j$ columns (the age classes). Following the method of
Gracia (1991), the total shrimp caught number at each month/age class combination $(i, j)$ was estimated.

Thus, the related process was:

1. From commercial shrimp catch classified by size categories of $P$. aztecus, it was assumed that weight (wi) of the shrimp tails at each size category is distributed in a regular manner $N(0,1)$. Based on these criteria, averages and standard deviations were calculated at each size category to estimate the probabilities of weight for each shrimp tail $\mathrm{P}(w i)$.

2. For each size category the division of the total weight by its corresponding sum of probabilities $\mathrm{P}($ wi) generates a conversion factor (FCi). Then, to determine the total shrimp caught number (TSCN) for each shrimp tail, the following equation was used:

$$
\mathrm{TSCN}=[\mathrm{P}(\mathrm{ti}) \times \mathrm{FCi}] / \mathrm{ti}
$$

3. Obtained TSCN results were arranged by monthly and associated with generated age classes. Finally, catch-at-age data were generated, and the $\mathrm{N}$ matrix was completed.

This method was adapted for a combination of $P$. aztecus sexes, as data for separate sexes was not available between 1974 and 1995 .

\section{Natural mortality and virtual population analysis (VPA)}

The method of Cervantes-Hernández et al. (2016) was used to estimate the monthly natural mortality rate. From the $\mathrm{N}$ matrix, the total sum of $j$ columns was calculated for each $i$ row, and with this information, a new matrix called $Y_{N}$ was constructed. The $Y_{N}$ matrix was arranged in descending order to apply the negative exponential model:

$$
\mathrm{N}_{\text {esp }}=\mathrm{N}_{0} \times \exp ^{(-\mathrm{M} \times t)}
$$

were $\mathrm{N}_{\text {esp }}$ is the expected sum of caught shrimp, $\mathrm{N}_{0}$ is the initial population size, $t$ is the time in months, and $\mathrm{M}$ is the natural mortality rate.

The negative exponential model was resolved using the Bayesian method of likelihood with log-normal distribution (Haddon, 2011), allowing for the estimation of a single natural mortality rate value. For the present study, a single estimate of this rate was not considered as reliable (Ricker, 1975), because the natural mortality rate was not constant in the population of P. aztecus between 1974 and 1995. Therefore, the $\mathrm{Y}_{\mathrm{N}}$ matrix was re-sampled 1,000 times with replacement using the bootstrap technique, and after for each simulated re-sampling, the negative exponential model was applied using the Monte Carlo technique (Haddon, 2011). Thus 1,000 values were estimated for the natural mortality rate, and with these, a histogram of frequencies was generated (Zar, 1999). Estimated 
values for the natural mortality rate were analyzed in relation to the number of times that these estimates were repeated, and based on their respective frequencies; a confidence interval for the monthly natural mortality rate was established. This interval included the minimum and maximum natural mortality rates, with the most frequent repeats between 1974 and 1995.

The negative exponential model was not applied to a single shrimp cohort from the $\mathrm{N}$ matrix because an estimated natural mortality rate for a single cohort is not representative of the shrimp population (Ramos-Cruz et $a l .$, 2006). Therefore, the $\mathrm{Y}_{\mathrm{N}}$ matrix was constructed, incorporating all monthly $P$. aztecus cohorts to generate a representative study. For exploited populations, Paloheimo (1961) and Berry (1967) suggested that all available cohorts should be considered to estimate the natural mortality rate correctly.

In the present study, since the $\mathrm{N}_{0}$ parameter is a general shrimp-catch value and this analysis is related to shrimp-catch numbers by age classes, this parameter was not used because it was not required in the subsequent analysis.

In fisheries research, the VPA is used to iteratively construct total population abundance in past years via past or current catch records (fishery recruitment data) (Hilborn \& Walters, 1992); the following data are required to develop the VPA: 1) the monthly natural mortality rate value, and 2) a matrix type such as the $\mathrm{N}$ matrix. For this reason, the $\mathrm{N}$ matrix was constructed, and a confidence interval for the monthly natural mortality rate was established. Two matrices were generated from VPA, the first matrix was called "shrimp abundance reconstruction by age classes" or $\mathrm{N}_{\mathrm{VPA}}$ matrix, and the second matrix was called "fishing mortality estimation by age classes" or Fe-vPA matrix. Both matrices have the same $i$ rows (for months) and $j$ columns (for age classes) such as $\mathrm{N}$ matrix.

Direct interactions between $P$. aztecus and other populations in $\mathrm{T}-\mathrm{V}$ area were not considered in the VPA. However, effects on natural mortality caused by density-dependence and density-independence (Beverton \& Holt, 1957) were indirectly included in the N $\mathrm{N}_{\mathrm{VPA}}$ matrix via the age-cohort analysis of Pope (1972). Thus, during shrimp abundance reconstruction by age classes, each cohort's monthly had a shrimp removal equal to the maximum natural mortality rate. So, shrimp that died of natural causes were not included in the $\mathrm{N}_{\mathrm{VPA}}$ matrix.

Mortality analysis and the VPA were programmed and executed in PopTools v.2.7.5.

\section{Population indices}

Two population indices were constructed for the population of $P$. aztecus, and these were made in accordance with Cervantes-Hernández (2008) as follow:

1. Based on matrix operations described by Pielou (1984), a correlation matrix for the age classes including in the $\mathrm{N}_{\mathrm{VPA}}$ matrix, was estimated.

2. A principal component analysis (PCA) was applied to the mentioned correlation matrix to perform a statistical separation of the age classes into two principal components or population indices. These were called as following: 1) SI index and 2) RI index.

3. The significant factor loading values greater than or equal to 0.70 were used to identify and validate into SI and RI indices, the age classes that can be correctly considered as spawners and young recruits.

4. Following Hair et al. (1999), negative factor loading values were interpreted applying their respective absolute values.

5. Once population indices were structured, two multiple linear functions were constructed to made SI and RI time series:

$$
\mathrm{SI}=\mathrm{RI}=\lambda_{i} \times \mathrm{E}_{x i}
$$

where $\lambda_{\mathrm{i}}$ are the linear coefficients or estimated eigenvectors for each $i$ age class with significant factor loading found into the SI index or RI index. $\mathrm{E}_{x i}$ is the virtual abundance in the month $x$ for $i$ age class included in the $\mathrm{N}_{\mathrm{VPA}}$ matrix.

\section{Reproductive seasons (lagoon recruitment) and recruitment seasons (marine recruitment)}

Estimated time series were analyzed with the CENSUS method to estimate their "harmonic patternsof variations (HPV)" (these are referred to as seasonal factors in Statistica v.7.0) (Cervantes-Hernández et al., 2016). With HPV mathematical transformation, monthly cyclical anomalies for SI and RI time series were generated. The monthly cyclical anomalies can be positive or negative, with the zero value as the midpoint of change. Positive cyclical anomalies represented the increases in the abundance of spawners and recruits, and negative cyclical anomalies represented decreases. Specifically, the positive cyclical anomalies were used to describe how the abundance of spawners and recruits changed throughout a whole year, and this information was, in turn, used to establish when lagoon and marine recruitment seasons began, ended, and reached maximum abundance in $\mathrm{T}-\mathrm{V}$ area. In this study, the estimated cyclical anomalies time series were called HPV-SI for the SI index and HPV-RI for the RI index. $\mathrm{ACP}$ and the CENSUS method were applied via Statistica v.7.0. 


\section{Fishing mortality and exploitation assessment}

Using Fe-vpa matrix data, a mean value of fishing mortality rate were estimated for each age class (Ramos-Cruz et al., 2006; Cervantes-Hernández, 2008), and with this information, the exploitation pattern by age classes was explained. Based on those mentioned above, the age classes that were overfished and under-fished were identified. Afterward, all estimated fishing mortality rates were averaged to approximate the total fishing mortality rate value $(\mathrm{F})$, with the model:

$$
\mathrm{Z}=\mathrm{F}+\mathrm{M}
$$

(Beverton \& Holt, 1957; Ricker, 1975), the total mortality $(Z)$ was approximated $(M$ is the maximum natural mortality rate value included in the confidence interval).

The spawners-recruits relationship model of Ricker (1975) was used to make an exploitation assessment of $P$. aztecus fishery. With the model aforementioned, a critical exploitation zone was established to separate possible periods of exploitation. For these periods, it was corroborated if spawners were highly exploited compared to young recruits or whether the opposite happened.

The complete fishery analysis process is shown in Table 1.

\section{RESULTS}

\section{Ageclasses, natural mortality and VPA}

The age structure for the population of Penaeus aztecus was composed of 16 age classes, between 3 and 16 months old. Respective shrimp tail weight ranges were 4-6 g (3 months old), 7-10 g (4 months old), 11-14 g (5 months old), 15-19 g (6 months old), 20-24 g (7 months old), 25-28 g (8 months old), 29-33 g (9 months old), 34-37 g (10 months old), 38-41 g (11 months old), 42$44 \mathrm{~g}$ (12 months old), 45-47 g (13 months old), 48-50 g (14 months old), 51-52 g (15 months old) and >53 g (16 months old).

The $\mathrm{N}$ matrix was composed of 264 months and 16 age classes. A reliable interval for the monthly natural mortality rate from 0.15 to 0.20 was established with a repeat frequency of $70 \%$ and 0.05 standard deviation. The monthly natural mortality rate of 0.20 was used to perform the VPA with the N matrix.

\section{Population indices}

Two principal components were generated by the PCA, $\mathrm{Cp} 1=\mathrm{SI}$ index (eigenvalue $=7.36$ ) and $\mathrm{Cp} 2=\mathrm{RI}$ index (eigenvalue $=2.46$ ). The estimated statistical variance to order 16 age classes into two principal components was $80 \%(61 \%+20 \%)$. The SI index presented significant factor loading in the age classes of $6,7,8,9$, 10,11, 12 and 13 months old, while in the RI index, a significant factor loading in the age class of 4 months old was recorded (Table 2, Eq. 8).

Obtained SI and RI time series are shown in Figure 2 , and these were structured using the following multiple linear functions:

$\mathrm{SI}=0.30 \times \mathrm{E}_{6}+0.16 \times \mathrm{E}_{7}-0.25 \times \mathrm{E}_{8}-0.41 \times \mathrm{E}_{9}+0.68 \times \mathrm{E}_{10}-0.17$

$\times \mathrm{E}_{11}-0.05 \times \mathrm{E}_{12}-0.03 \times \mathrm{E}_{13}$

$\mathrm{RI}=0.41 \times \mathrm{E}_{4}$

were, $\mathrm{E}_{i}$ are specific age classes.

Reproductive seasons (lagoon recruitment) and recruitment seasons (marine recruitment)

The original time series for the SI index is shown in Figure 2. The spawners of $P$. aztecus were present throughout the whole year. Based on the HPV-SI (Fig. 3 ), it was concluded that approximately a complete lagoon recruitment season spanned from middle December to early May, with the highest signal in the abundance of spawners during February.

The original time series for the RI index is shown in Figure 2. The recruits of $P$. aztecus were present throughout the whole year. Based on the HPV-RI (Fig. 3 ), it was concluded that approximately a complete marine recruitment season spanned from early April to middle September, with the highest signal in the abundance of recruits during June/July.

\section{Fishing mortality and exploitation assessment}

The fishing mortality rate by age classes had a sustained increase between 4 ( 0.23 monthly) and $>14$ months old (>0.99 monthly) (Fig. 4). The lowest rate was observed in the age class of 3 months old ( 0.03 monthly), and this was followed by the relatively low rates found in the age classes from 4 to 5 months old (the average monthly rate was estimated at 0.30). Medium rates were recorded in the age classes from 6 to 13 months old (the average monthly rate was estimated at 0.60 ). The highest rates were recorded in the age classes from 14 to 16 months old (>0.99 monthly).

The total monthly $\mathrm{F}$ rate value was estimated at 0.5 monthly, and considering the monthly value of the natural mortality rate at 0.20 , the total monthly $\mathrm{Z}$ rate value was estimated at 0.74 monthly.

From 1974 to early 1991 (the first exploitation period), critical abundance levels for spawners $\left(\sim 16 \times 10^{7}\right.$ shrimp at average $)$ and recruits $\left(\sim 73 \times 10^{7}\right.$ shrimp at average) were recorded inside the critical exploitation zone (Fig. 5). On the other hand, a recovery in abundance for spawners $\left(\sim 28 \times 10^{7}\right.$ shrimp at average $)$ and recruits $\left(\sim 115 \times 10^{7}\right.$ shrimp at average $)$ 
Table 1. Complete fishery analysis process description. $\mathrm{N}$ matrix: caught shrimp by age classes, $\mathrm{Y}_{\mathrm{N}}$ matrix: representative population cohort of Penaeus aztecus, VPA: virtual population analysis, $\mathrm{N}_{\mathrm{VPA}}$ matrix: shrimp abundance reconstruction by age classes, Fe-vPA matrix: fishing mortality estimation by age classes, PCA: principal components analysis, SI index: the abundance of spawners, RI index: the abundance of recruits, HPV-SI: harmonic patterns of variations for SI index, HPVRI: harmonic patterns of variations for RI index, F: total fishing mortality rate, Z: the total mortality rate.

\begin{tabular}{|c|c|}
\hline Process 1 & $\begin{array}{l}\text { input: monthly shrimp commercial catch classified by size categories } \\
\text { output: age classes estimation } \\
\text { output: } N \text { matrix } \\
\text { output: } Y_{N} \text { matrix }\end{array}$ \\
\hline Process 2 & $\begin{array}{l}\text { input: } Y_{N} \text { matrix } \\
\text { output: natural mortality rate }(M) \text { interval estimation }\end{array}$ \\
\hline Process 3 & $\begin{array}{l}\text { inputs: } \mathrm{N} \text { matrix, maximum } \mathrm{M} \text { value, and VPA application } \\
\text { output: } \mathrm{N}_{\mathrm{VPA}} \text { matrix } \\
\text { output: } \mathrm{Fe} \text {-VPA matrix }\end{array}$ \\
\hline Process 4 & $\begin{array}{l}\text { inputs: } \mathrm{N}_{\mathrm{VPA}} \text { matrix, and PCA application } \\
\text { output: SI and RI indices } \\
\text { output: SI and RI time series }\end{array}$ \\
\hline Process 5 & $\begin{array}{l}\text { input: SI, RI time series, and CENSUS method application } \\
\text { output: HPV-SI and HPV-RI time series } \\
\text { output: lagoon season and marine season delimitation }\end{array}$ \\
\hline Process 6 & $\begin{array}{l}\text { input: Fe-vPAmatrix } \\
\text { output: fishing mortality rates by age classes } \\
\text { output: } \mathrm{F} \text { and } \mathrm{Z} \text { rates estimation } \\
\text { output: spawners-recruits relationship model estimation } \\
\text { output: exploitation assessment }\end{array}$ \\
\hline
\end{tabular}

Table 2. Estimated factor loadings by age classes (Ei) into SI (the abundance of spawners), and RI (the abundance of recruits) indices. Eigenvalues (ev), statistical variance of ordination (sv = eigenvalue/12 age classes). The marked values are factor loading values greater than or equal to $0.70(P<0.05)$. The absolute value was applied to interpret negative factor loading values.

\begin{tabular}{ccccccccccccccccc}
\hline & $\mathrm{E}_{3}$ & $\mathrm{E}_{4}$ & $\mathrm{E}_{5}$ & $\mathrm{E}_{6}$ & $\mathrm{E}_{7}$ & $\mathrm{E}_{8}$ & $\mathrm{E}_{9}$ & $\mathrm{E}_{10}$ & $\mathrm{E}_{11}$ & $\mathrm{E}_{12}$ & $\mathrm{E}_{13}$ & $\mathrm{E}_{14}$ & $\mathrm{E}_{15}$ & $\mathrm{E}_{16}$ & $\mathrm{ev}$ & $\mathrm{sv}$ \\
\hline $\mathrm{SI}$ & 0.34 & 0.53 & 0.66 & $* 0.79$ & $* 0.88$ & $* 0.93$ & $* 0.93$ & $* 0.91$ & $* 0.86$ & $* 0.81$ & $* 0.74$ & 0.58 & 0.43 & 0.34 & 7.36 & $61 \%$ \\
$\mathrm{RI}$ & - & - & - & -0.47 & -0.17 & 0.09 & 0.27 & 0.32 & 0.35 & 0.33 & 0.27 & 0.17 & 0.10 & 0.28 & 2.46 & $20 \%$ \\
& 0.69 & $* 0.81$ & 0.69 & & & & & & & & & & & & & \\
\hline
\end{tabular}

was recorded outside the critical exploitation zone from 1992 to 1993 (the second exploitation period) (Fig. 5). In both exploitation periods, a higher exploitation level of spawners than for young recruits was observed. However, those mentioned above were more evident in the first exploitation period.

\section{DISCUSSION}

\section{Age classes}

In $\mathrm{T}-\mathrm{V}$ area, the estimated age structure for the population of Penaeus aztecus was the same as for other Mexican shrimp populations where the age classes were estimated using commercial shrimp catch classified by size categories. In the gulfs of Mexico and Tehuantepec, the age structure was documented between 3 and 16 months old for the populations of $P$. duorarum (Cervantes-Hernández \& Gracia, 2011), $P$. californiensis (Cervantes-Hernández, 2008), and $P$. vannamei (Cervantes-Hernández et al., 2008a).

The apparent similarity between the age structures in Mexican shrimp populations is due to the fact that their reported length growth parameters are partially consistent. For P.aztecus $\left[\mathrm{L}_{\infty}=204 \mathrm{~mm}, \mathrm{t}_{0}=-0.2914\right.$ $\mathrm{mm}, \mathrm{k}=0.215$ monthly] (Gracia, 1997). For $P$. californiensis $\left[\mathrm{L}_{\infty}=242 \mathrm{~mm}, \mathrm{t}_{0}=-0.344 \mathrm{~mm}, \mathrm{k}=0.186\right.$ monthly] and for $P$. vannamei $\left[\mathrm{L}_{\infty}=200 \mathrm{~mm}, \mathrm{t}_{0}=\right.$ $-0.293 \mathrm{~mm}, \mathrm{k}=0.266$ monthly] (Chávez, 1979). For $P$. duorarum $\left[\mathrm{L}_{\infty}=203 \mathrm{~mm}, \mathrm{t}_{0}=-0.466 \mathrm{~mm}, \mathrm{k}=0.216\right.$ monthly] (Gracia, 1995).

Similar results for the age structure were documented for $P$. californiensis in Sonora, Mexico (López-Martínez et al., 2003), and for Penaeus notialis Pérez-Farfante, 1967 in the Araya Peninsula, Venezuela (Marval-Rodríguez et al., 2015). 


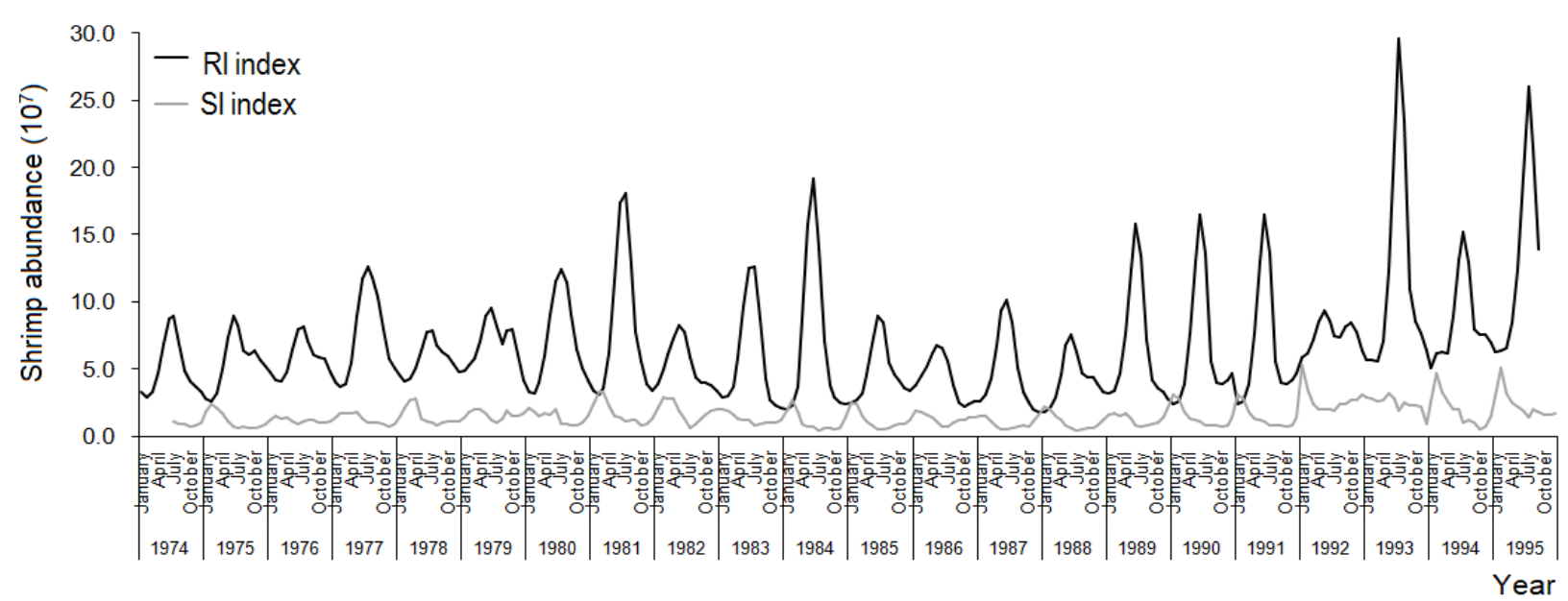

Figure 2. Abundance time series for spawners (SI index) and recruits (RI index).

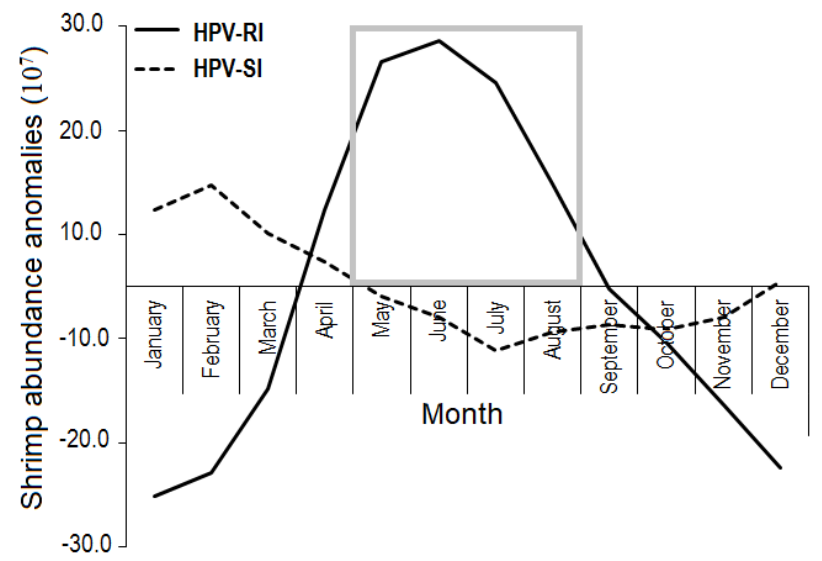

Figure 3. Monthly shrimp abundance anomalies shown a seasonal cycle for HPV-SI (harmonic patterns of variations for SI index), and HPV-RI (harmonic patterns of variations for RI index). A marine closure season is shown with a gray rectangle (explanation in the text).

Length growth parameters reported by Gracia (1997) documented the 1983-1992 period, a period completely overlapping, therefore, with the present study.

\section{Natural mortality and VPA}

In $\mathrm{T}-\mathrm{V}$ area studies on the natural mortality of $P$. aztecus are scarcely documented (Klima, 1989; Arreguín-Sánchez et al., 1997; Gracia, 1997). The mentioned studies were taken into account to make a literature reference interval for the natural monthly mortality rate of between 0.19 and 0.31 monthly. In the present study, the natural monthly mortality rate ranged from 0.15 to 0.20 . Since the estimated maximum value for the natural monthly mortality rate resulted within the literature reference interval, this value was used to perform the VPA.

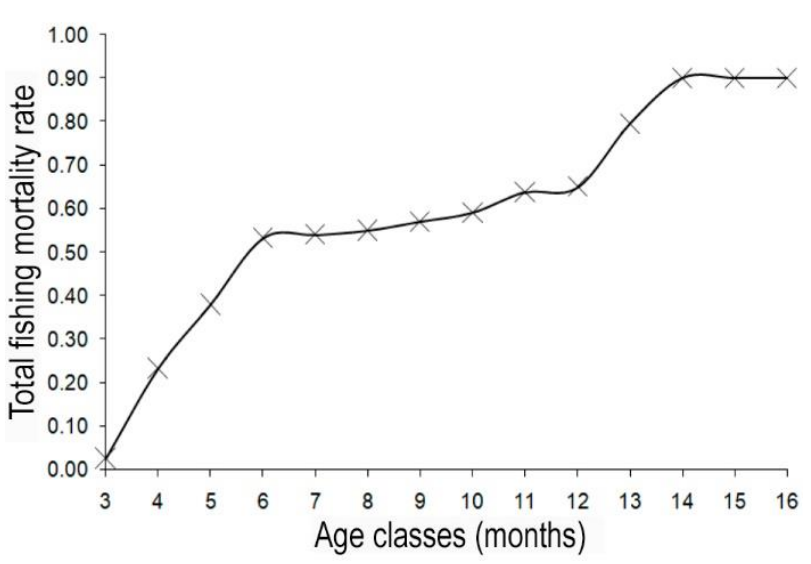

Figure 4. Estimated exploitation pattern by age classes in the population of Penaeus aztecus.

In the present study, the estimated natural monthly mortality rate at 0.20 was consistent with estimated natural monthly mortality rates in other Mexican shrimp populations. In the Gulf of Mexico, monthly M rates were documented for the populations of $P$. setiferus (at 0.25) (Gracia, 1989) and P. duorarum (at 0.22) (Cervantes-Hernández, 1999; CervantesHernández \& Gracia, 2011). In the Gulf of Tehuantepec, monthly $\mathrm{M}$ rates were reported for the populations of $P$. californiensis (at 0.22), and $P$. vannamei (at 0.20) (Ramos-Cruz et al., 2006). Similar results were documented for the populations of $P$. californiensis, $P$. vannamei, and Penaeus stylirostris in the Gulf of California, Mexico (Aranceta-Garza et al., 2016).

Obtained results and the studies, as mentioned earlier, suggest that the most reliable interval for $\mathrm{M}$ rate in Mexican shrimp populations would be between 0.20 and 0.25 monthly. Following Gracia (1997), these M rate values appear to be reasonable and compatible with 


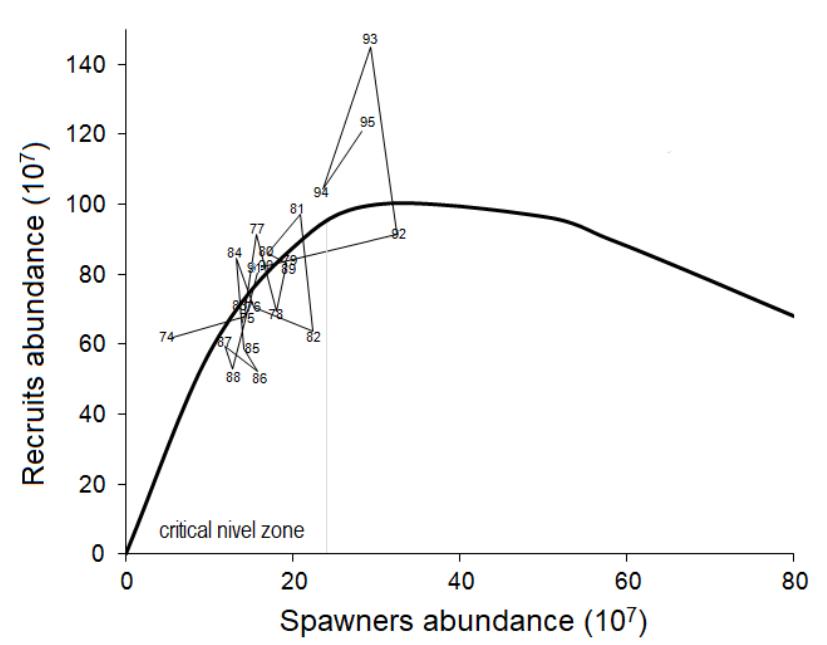

Figure 5. Annual spawners-recruits relationship model and exploitation assessment for the population of Penaeus aztecus from 1974 to 1995.

the annual life history of penaeid shrimp. For this reason, the minimum 0.15 value was not considered in order to perform VPA. These considerations governed the decision to use the 0.20 value in VPA.

\section{Population indices}

In SI index, the age classes of 6, 7, 8, 9, 10, 11, 12 and 13 months old were identified as spawners (Table 2). These ages were similar to spawner ages reported for the population of $P$. duorarum in the Sonda de Campeche area (Cervantes-Hernández \& Gracia, 2011), as well as for the populations of $P$. californiensis and $P$. vannamei in the Gulf of Tehuantepec (CervantesHernández, 2008; Cervantes-Hernández et al., 2008a).

Spawner age classes included in SI index were validated with recognition of the fact that in the Penaeidae family sexual maturity is prevalently reached between 6 and 7 months old, while the rest of the population is sexually mature when they are more than 8 months old (Gracia et al., 1997; CervantesHernández, 2008).

In the RI index, the age class of 4 months old represented to young shrimp recruits (Table 2). This age was equal to the marine recruitment age reported for the population of $P$. duorarum in the Sonda de Campeche area (Cervantes-Hernández \& Gracia, 2011), as well as for the populations of $P$. californiensis and $P$. vanname $i$ in the Gulf of Tehuantepec (Cervantes-Hernández, 2008; Cervantes-Hernández et al., 2008a). These reports suggest that marine recruitment age in Mexican shrimp populations is common for 4 months old.

\section{Reproductive season (lagoon recruitment)}

For the population of $P$. aztecus in $\mathrm{T}-\mathrm{V}$ area, a complete lagoon recruitment season spanned from middle
December to early May, with the highest signal in the abundance of spawners during February (Fig. 3). These results were consistent with other Mexican shrimp populations where the commercial shrimp catch classified by size categories was recorded. In the Sonda de Campeche area, the populations of $P$. duorarum and $P$. setiferus were documented with a high abundance of spawners from October to February (Gracia \& Soto, 1990; Cervantes-Hernández \& Gracia, 2011). In the case of the population of $P$. californiensis in the Gulf of Tehuantepec, a complete lagoon recruitment season spanned from July to February, with the highest signal in the abundance of spawners during October/ November (Cervantes-Hernández et al., 2008b).These reports suggest that Mexican shrimp populations have higher reproductive activity during late autumn and winter.

Supplementary, in Quintana Roo, Mexico, higher reproductive activity during October/November was reported for $P$. brasiliensis (Sandoval-Quintero \& Gracia, 1998). Also, higher reproductive activity in winter seasons (mainly from September to October) was reported for the populations of $P$. notialis in the Araya Peninsula, Venezuela (Marval-Rodríguez et al., 2015), and P. duorarum in the Gulf of Ana Maria, Cuba (Giménez-Hurtado et al., 2012).

Cervantes-Hernández et al. (2008b) explained why Mexican shrimp populations have high reproductive activity during late autumn and winter. In the Gulf of Tehuantepec, $P$. californiensis reproduces in winter when oceanographic conditions are with higher Chlorophyll- $a$ levels (Chl- $a, \sim 1.10 \mathrm{mg} \mathrm{m}^{-3}$ ) and colder sea surface temperature $\left(\mathrm{SST}, \sim 26-27^{\circ} \mathrm{C}\right)$. The presence of Chl- $a$ is relevant because it is with this that the trophic chain is activated, and shrimp's larval stages can feed directly on phytoplankton and zooplankton biomass. Therefore, higher Chl- $a$ levels promote the survival of shrimp's post-larvae, increasing lagoon recruitment.

In the Gulf of Mexico, Chl- $a$ levels were recorded $>1.0 \mathrm{mg} \mathrm{m}^{-3}$ from November to January, and $<1.0 \mathrm{mg}$ $\mathrm{m}^{-3}$ between April and October (1998-2008 period) (Salmerón-García et al., 2011). During winter in T-V area, Chl- $a$ concentrations ranged from 0.5 to $1.0 \mathrm{mg} \mathrm{m}^{-3}$, and the SST from 21 to $24^{\circ} \mathrm{C}$ was recorded (CervantesHernández, 2015). In a complementary study conducted in the gulfs of Mexico and Tehuantepec, RomeroCenteno \& Zavala-Hidalgo (2003) indicated that a high Chl- $a$ level is related to immense offshore transport caused by stronger winds in winter from December to January, while the effect of the wind is at its minimum in summer between May and June.

To determine the reproductive season of $P$. setiferus and $P$. duorarum, Flores-Coto et al. (2018) and Gómez- 
Ponce et al. (2018) estimated the density of the postlarvae that entered Terminos Lagoon. The maximum post-larvae density occurred from June to September during the rainy season, and the minimum post-larvae density was reported during winter.

When closure seasons did not exist in the Gulf of Mexico, Gracia (1989) estimated the density of the post-larvae that entered Terminos Lagoon and concluded that Mexican shrimp populations have on two reproductive seasons. The first reproductive season is as was reported for the population of $P$. aztecus in the present study (Figs. 2-3). The second reproductive season is as was documented for the populations of $P$. setiferus and $P$. duorarum by Flores-Coto et al. (2018) and Gómez-Ponce et al. (2018).

On the other hand, Gracia (1991) reported that due to changes in oceanographic conditions, the post-larvae density is highest during the first reproductive season. These details have implications for shrimp populations in the Gulf of Mexico because recent closure seasons have been implanted between May and August/ September/October (SAGARPA-INP, 2012). Thus, it is clear that closure seasons are implanted throughout the second reproductive season, and the first reproductive season is completely unprotected (Fig. 3).

In response to that mentioned by Flores-Coto et al.(2018) and Gómez-Ponce et al. (2018), about minimum postlarvae density recorded in winter, it was concluded that their method of estimation did not work during the first reproductive season because fishing effort quickly reduces the abundance of spawners in the marine environment, thus as an immediate response, post-larvae abundance abruptly declines. Its entrance into lagoon systems becomes almost undetectable. When closure seasons are implemented, the opposite case occurs; fishing effort does not affect the abundance of spawners in the marine environment, thus as an immediate response, post-larvae abundance does not decline, and its entrance into lagoon systems can detect with the mentioned method.

In the present study, the post-larvae density of $P$. aztecus was not measured, but in accordance with Gracia (1991), it was indirectly observed that during the first reproductive season, the abundance of spawners was highest than during rainy season (Figs. 2-3). Gracia et al. (1997) indicated that generally, in shrimp populations, the massive post-larval density coincides with an increase in the abundance of spawners in the marine environment (lagoon recruitment).

In the Gulf of Tehuantepec, the maximum percentage of brown shrimp mature females in phase IV was reported from October to January (in the first reproductive season), and the minimum percentage was documented from July to September (in the second reproductive season) (Cervantes-Hernández, 2008). Similar results were documented in the Campeche Bank area by SAGARPA-INP (2012). These results support the conclusion of Cervantes-Hernández et al. (2008b) that in the first reproductive period, higher concentrations of Chl- $a$ promoted the survival of shrimp's post-larvae, increasing the lagoon recruitment between late autumn and winter.

From obtained results, it was concluded that in the Gulf of Mexico, the populations of P. aztecus (Figs. 2$3), P$. setiferus and $P$. duorarum have two reproductive seasons throughout the whole year. Nevertheless, this must be recognized that the fishery analysis process undertaken in the present study (Table 1) could not detect the second reproductive season because the information analyzed referred to shrimp caught in the marine environment (fishery recruitment). On the other hand, the post-larvae density method cannot detect the first reproductive season because information about shrimp caught in the marine environment is not, in this case, included. Thus, both methods are complementary. For this reason, it is recommended that these studies are performed perpetually in the Gulf of Mexico.

\section{Recruitment season (marine recruitment)}

For the population of P. aztecus in T-V area, a complete marine recruitment season spanned from early April to middle September, with the highest signal in the abundance of recruits during June (Fig. 3). These results were consistent with other Mexican shrimp fisheries where the commercial shrimp catch classified by size categories was recorded.

In the Sonda de Campeche area, the P. setiferus and $P$. duorarum populations were documented with a high abundance of recruits during June/July, and May/June (Gracia \& Soto, 1990; Cervantes-Hernández, 1999). In the cases of the $P$. californiensis and $P$. vannamei populations in the Gulf of Tehuantepec, a complete marine recruitment season spanned from April to October (with the highest signal in the abundance of a recruit during July/August), and from April to August (with the highest signal in the abundance of a young recruit during June/July) (Cervantes-Hernández et al., 2008a; Cervantes-Hernández et al., 2017). Also, a higher abundance of recruits from July to August was reported for the $P$. notialis population in the Gulf of Ana Maria, Cuba (Giménez-Hurtado et al., 2012). These reports suggest that Mexican shrimp populations have higher marine recruitment activity during the rainy season.

\section{Fishing mortality and exploitation management}

Like in the population of $P$. aztecus at 3 months old $(\mathrm{F}=0.03$ monthly) (Fig. 4), the lowest fishing mortality 
rates are documented for this same age class in the populations of $P$. californiensis, $P$. vannamei (RamosCruz et al., 2006), and P. duorarum (CervantesHernández, 1999; Cervantes-Hernández \& Gracia, 2011). They suggest that in Mexican shrimp populations, this age class is not intensively exploited (Cervantes-Hernández et al., 2017) because usually, this age class is more abundant within lagoon systems. The age classes from 4 to 5 months old were recorded with relative low fishing mortality rates (the average monthly rate was estimated at 0.30) (Fig. 4). For this reason, they were partially included in the records of commercial shrimp catch classified by size categories. For these latter age classes, similar exploitation levels are documented in the aforementioned Mexican shrimp populations.

The highest rates were recorded in the age classes from 14 to 16 months old (>F = 0.99 monthly) (Fig. 4). Similar exploitation levels are documented for these same age classes in populations of $P$. californiensis, $P$. vannamei (Ramos-Cruz et al., 2006), and P. duorarum (Cervantes-Hernández, 1999; Cervantes-Hernández \& Gracia, 2011). Suggesting that in Mexican shrimp fisheries, these age classes are more intensively exploited (Cervantes-Hernández et al., 2017), and thus in $\mathrm{T}-\mathrm{V}$ area they were scarcely included in the records of commercial shrimp catch classified by size categories. For this reason, in the SI index, statistically, these age classes did not show significant factor loading values greater than or equal to 0.70 .

Medium rates were recorded in the age classes from 6 to 13 months old (the average monthly rate was estimated at 0.60) (Fig. 4). Although these exploitation levels were considered high, it was concluded that these age classes had maintained the continuity of this shrimp fishery from 1974 to 1991. As was estimated, these age classes were dominant in commercial shrimp catch classified by size categories.

In both exploitation periods, a higher exploitation level of spawners than for young recruits was observed. However, those above were more evident in the first exploitation period. Thus, it was concluded that in $\mathrm{T}-\mathrm{V}$ area the population of $P$. aztecus was higher over-fished between 1974 and 1991. The apparent recovery in spawners and recruits abundance during the second period was associated with the experimental closure works conducted in the Gulf of Mexico before the official closure season was implemented.

Recently, the fishery of $P$. aztecus was recorded with a total production of 13,210 t (SAGARPACONAPESCA, 2017), and during this study, the total production was reported at 10,000 t (Arreguín-Sánchez \& Chávez, 1985). In conclusion, closure season implementation has maintained almost equal catch levels since 1993, probably because the first reproductive season is completely unprotected (Fig. 3).

Closure seasons are not beneficial for $P$. duorarum and $P$. setiferus populations because they are documented as over-fished in the Sonda de Campeche. This difference in comparison to the populations of $P$. aztecus is due to an increase in the oil industry activities in the Gulf of Mexico south region, as marine and lagoon recruitment are being negatively affected by these actions (Cervantes-Hernández \& Gracia, 2011). Finally, it is important to consider that as the population of $P$. aztecus, the first reproductive season is wholly unprotected in $P$. duorarum and $P$. setiferus.

\section{ACKNOWLEDGMENTS}

We would like to thank the Regional Centers for Fisheries Research from Tamaulipas and Veracruz for providing the data used in this study, the Crustacean Fisheries Ecology Laboratory UNAM, and UMAR for resources provided. We wish to thank Misto Matthews and Jeff Gillon for editing this manuscript and anonymous reviewers for comments that significantly improved the final version.

\section{REFERENCES}

Aranceta-Garza, F., Arreguín-Sánchez, F., Ponce-Díaz, G. \& Seijo, J.C. 2016. Natural mortality of three commercial penaeid shrimps (Litopenaeus vannamei, $L$. stylirostris and Farfantepenaeus californiensis) of the Gulf of California using gnomonic time divisions. Scientia Marina, 80(2):1-8.

Arreguín-Sánchez, F. \& Chávez, E.A. 1985. Estado del conocimiento de las pesquerías de camarón en el Golfo de México. CICIMAR Oceánides, 2(2): 23-44.

Arreguín-Sánchez, F., Schultz-Ruiz, L., Gracia, A., Sánchez, J.A. \& Alarcón, T. 1997. Las pesquerías de camarón de altamar: explotación, dinámica y explotación. In: Flores-Hernández, D., Sánchez-Gil, D., Seijo, J.C. \& Arreguín-Sánchez, F. (Eds.). Análisis y diagnóstico de los recursos pesqueros críticos del Golfo de México. EPOMEX, Serie Científica, Campeche, pp. 145-172.

Berry, R. 1967. Dynamic of the Tortugas pink shrimp population. Ph.D. Thesis, University of Rhode Island, Rhode Island, $160 \mathrm{pp}$.

Beverton, R.J.H. \& Holt, S.J. 1957. On the dynamics of exploited fish population. Fishery Investigations, Serie 2, Volume 19, London.

Cervantes-Hernández, P. 1999. Relaciones stockreclutamiento del camarón rosado Farfantepenaeus duorarum (Burkenroad, 1939) en el Banco de 
Campeche. Tesis de Magíster, Universidad Nacional Autónoma de México, Ciudad de México, 35 pp.

Cervantes-Hernández, P. 2008. Method to obtain indices of abundance in the population of brown shrimp from the Gulf of Tehuantepec, Oaxaca, Mexico. Revista de Biología Marina y Oceanografía, 43(1): 111-119.

Cervantes-Hernández, P. 2015. Modelación de las fluctuaciones de la abundancia del camarón café Farfantepenaeus aztecus (Ives, 1891). Tesis de Doctorado, Universidad Nacional Autónoma de México, Ciudad de México, 48 pp.

Cervantes-Hernández, P. \& Gracia, A. 2011. Análisis de la mortalidad para el camarón rosado Farfantepenaeus duorarum (Decapoda, Dendrobranchiata) del Banco de Campeche, México. Pan-American Journal of Aquatic Sciences, 6(2): 100-108.

Cervantes-Hernández, P., Michel-Morfin, J.E. \& Gallardo-Berumen, M.I. 2016. Reproductive and recruitment seasons of the purple snail Plicopurpurapansa (Gould 1853) in Oaxaca, Mexico. Journal of Shellfish Research, 35(4): 993-1005.

Cervantes-Hernández, P., Torres-Hernández, P. \& Gómez-Ponce, M.A. 2017. Recruitment age of Litopenaeus vannamei (Boone, 1931) (Decapoda: Penaeidae) in the Cabeza de Toro-La Joya Buenavista lagoon system, Oaxaca-Chiapas, Mexico. Open Journal of Marine Science, 7: 511-525.

Cervantes-Hernández, P., Gallardo-Berumen, M.I., Ramos-Cruz, S., Gómez-Ponce, M.A. \& Gracia, A. 2008a. Análisis de las temporadas de veda en la explotación marina de camarones del Golfo de Tehuantepec, México. Revista de Biología Marina y Oceanografía, 43(2): 285-294.

Cervantes-Hernández, P., Sánchez-Meraz, B., SerranoGuzmán, S.J., Frías-Velasco, A., Ramos-Cruz, S. \& Gracia, A. 2008b. Variación interanual de la abundancia de Farfantepenaeus californiensis (Holmes, 1900) en el Golfo de Tehuantepec. Hidrobiológica, 18(3): 215-226.

Chávez, E.A. 1979. Diagnosis de la pesquería del camarón del Golfo de Tehuantepec, Pacífico Sur Occidental de México. Anales del Instituto de Ciencias del Mar y Limnología, 6(2): 15-44.

Flores-Coto, C., Embriz-Alba, D., Gómez-Ponce, M.A., López-Martínez, J. \& Sanvicente-Añorve, L. 2018. Immigration of post larvae of penaeid shrimp to Términos Lagoon, Campeche, México: 2013 annual cycle. Open Journal of Marine Science, 8: 522-535.

Giménez-Hurtado, E., Alzugaray-Martínez, R., GarcésRodríguez, Y., Delgado-Miranda, G. \& VenturaFlores, A. 2012. Reclutamiento del camarón rosado Fafantepenaeus notialis (Decapoda: Penaeidae) en el Golfo de Ana María, Cuba. Serie Oceanología, 10: 7789.
Gómez-Ponce, M.A., Flores-Coto, C., López-Martínez, J., Cruz-Sánchez, J.L. \& Sanvicente-Añorve, L. 2018. Evaluation of the entry white shrimp postlarvae (Decapoda: Penaeidae) to a nursery area in the souther Gulf of Mexico. Latin American Journal of Aquatic Research, 46(1): 166-175.

Gómez-Márquez, J.L. 1994. Métodos para determinar la edad de los organismos acuáticos. Facultad de Estudios Superiores, Universidad Nacional Autónoma de México, Ciudad de México, 89 pp.

Gracia, A. 1989. Relationship between environmental factors and white shrimp abundance in the southwestern Gulf of Mexico. Anales del Instituto de Ciencias del Mar y Limnología, 14: 171-182.

Gracia, A. 1991. Spawning stock-recruitment relationship of white shrimp in the southwestern Gulf of Mexico. Transactions of the American Fisheries Society, 120: 519-527.

Gracia, A. 1995. Impacto de la pesca artesanal sobre la producción del camarón rosado Penaeus farfantepenaeus duorarum Burkenroad, 1939. Ciencias Marinas, 21: 343-359.

Gracia, A. 1997. Simulated and actual effects of the brown shrimp, Penaeus aztecus, closure in Mexico. Marine and Freshwater Research, 59(2): 18-24.

Gracia, A. 2004. Aprovechamiento y conservación del recurso camarón. In: Caso, M., Pisanty, M.I. \& Ezcurra, E. (Eds.). Diagnóstico ambiental del Golfo de México. Secretaría de Agricultura, Ganadería, Desarrollo Rural, Pesca y Alimentación - Harte Research Institute for the Gulf of Mexico Studies, Ciudad de México, pp. 713-725.

Gracia, A. \& L. Soto. 1990. Populations study of the penaeid shrimp of Terminos Lagoon, Campeche, Mexico. Anales del Instituto de Ciencias del Mar y Limnología, 17(2): 241-255.

Gracia, A., Vázquez-Bader, A.R., Arreguín-Sánchez, F., Schultz-Ruiz, L.E. \& Sánchez, J.A. 1997. Ecología de camarones peneidos. In: Flores-Hernández, D., Sánchez-Gil, P., Seijo, J.C. \& Arreguín-Sánchez, F. (Eds.). Análisis y diagnóstico de los recursos pesqueros críticos del Golfo de México. EPOMEX Serie Científica, Campeche, pp. 127-144.

Haddon, M. 2011. Modeling and quantitative methods in fisheries. CRC Press, London.

Hair, F., Anderson, J., Tatham, L. \& Black, C. 1999. Multivariate data analysis. Prentice-Hall, New Jersey.

Hilborn, R. \& Walters, C.J. 1992. Quantitative fisheries stock assessment. Choice, dynamics and uncertainty. CRC Press, London.

Klima, E. 1989. Approaches to research and management of US fisheries for penaeid shrimp in the Gulf of Mexico. In: Caddy, F. (Ed.). Marine invertebrate 
fisheries: their assessment and management. John Wiley \& Sons, New York, pp. 281-306.

López-Martínez, J., Arreguín-Sánchez, F., HernándezVázquez, S., Garcia, A. \& Valenzuela, W. 2003. Interannual variation of growth of the brown shrimp Farfantepenaeus californiensis and its relation to temperature. Fisheries Research, 61(1-3): 95-105.

Marval-Rodríguez, A., Altuve, D., Ramírez, I., Alió, J., Gómez, G., Cedeño, K., Martínez, F. \& Ortiz, L. 2015. Crecimiento y mortalidad de Farfantepenaeus notialis en la costa norte de la Península de Araya, Venezuela. Zootecnia Tropical, 33(3): 193-205.

Paloheimo, J. 1961. Studies on estimation of mortalities. I. Comparison of a method described by Beverton and Holt and a new linear formula. Journal of the Fisheries Research Board of Canada, 18: 645-662.

Pielou, E. 1984. The interpretation of ecological data. John Wiley \& Sons, New York.

Pope, J.G. 1972. An investigation of the accuracy of virtual population analysis using cohort analysis. Fisheries Research Bulletin, 9: 65-74.

Ramos-Cruz, S., Sánchez-Meraz, B., Carrasco-Ayuso, F. \& Cervantes-Hernández, P. 2006. Estimación de la tasa de mortalidad natural de Farfantepenaeus californiensis Holmes, 1900 y Litopenaeus vannamei Boone, 1931, en la zona costera del Golfo de Tehuantepec, México. Revista de Biología Marina y Oceanografía, 41(2): 221-229.

Ricker, W. 1975. Computation and interpretation of biological statistic of fish population. Bulletin of the Fisheries Research Board of Canada, 191: 382 pp.
Romero-Centeno, R., Zavala-Hidalgo, J., Gallegos, A. \& O'Brien, J.J. 2003. Isthmus of Tehuantepec wind climatology and ENSO signal. Journal of Climate, 16: 2628-2639.

Secretaría de Agricultura, Ganadería, Desarrollo Rural, Pesca y Alimentación - Instituto Nacional de Pesca (SAGARPA-INP). 2012. Dictamen técnico. Fundamento técnico para el establecimiento de vedas para la pesca de camarón en el Golfo de México y Mar Caribe. SAGARPA-INP, Ciudad de México. [https://www. ina-pesca.gob.mx/portal/documentos/bolsadetrabajo/ 2012/DICTAMENCAMARON2012_GMYMC.pdf]. Reviewed: April 20, 2018.

Secretaría de Agricultura, Ganadería, Desarrollo Rural, Pesca y Alimentación - Comisión Nacional de Acuacultura y Pesca (SAGARPA-CONAPESCA). 2017. Anuario estadístico de acuacultura y pesca. [https://www.conapesca.gob.mx/work/sites/cona/dg ppe/2017/ANUARIO_ESTADISTICO_2017.pdf]. Reviewed: March 27, 2019.

Salmerón-García, O., Zavala-Hidalgo, J., Mateos-Jasso, A. \& Romero-Centeno, R. 2011. Regionalization of the Gulf of Mexico from space-time chlorophyll- $a$ concentration variability. Ocean Dynamics, 61: 439448.

Sandoval-Quintero, M.E. \& Gracia, A. 1998. Stages of gonadal development in the spotted pink shrimp Penaeus brasiliensis. Journal of Crustacean Biology, 18(4): 610-685.

Zar, H.J. 1999. Biostatistical analysis. Prentice-Hall, New Jersey.

Received: 1 August 2018; Accepted: 4 April 2020 